\title{
Não sei onde está a preposição (de) que a oração relativa precisa: as estratégias de relativização no português popular de Fortaleza sob a ótica variacionista
}

\section{I don't know where is the preposition (de) that the relative clause needs: the relativization strategies in popular portuguese in Fortaleza from a variationist perspective}

\author{
Aluiza Alves de Araújo* \\ Vinicius da Silva Vieira**
}

\section{RESUMO}

Com base nos pressupostos teórico-metodológicos da Sociolinguística Variacionista, este trabalho objetiva analisar a variação das estratégias de relativização na fala popular fortalezense. Os dados analisados foram extraídos da fala de 54 informantes em entrevistas sociolinguísticas do tipo DID (Diálogo entre Informante e Documentador), pertencentes ao banco de dados Projeto Norma Oral do Português Popular de Fortaleza (NORPOFOR). Em nossa amostra, encontramos um total de 883 ocorrências de orações relativas, havendo sobressaliência da estratégia de relativização cortadora em comparação à estratégia padrão. Para a estratégia cortadora, as variáveis beneficiadoras foram função sintática do pronome relativo (complemento relativo e adjunto adverbial), tipo de oração relativa (restritiva),

Recebido em 6 de dezembro de 2020.

Aceito em 1 de abril de 2021.

DOI: http://dx.doi.org/10.18364/rc.2021n61.484

*Universidade Estadual do Ceará, aluizazinha@hotmail.com, http://orcid.org/0000-0003-2166-0852

**Universidade Estadual do Ceará, viniciusfmjs@gmail.com, http://orcid.org/0000-0002-1740-3549 
preposição regida pelo verbo/nome (de e com) e traço semântico \pm definido do antecedente (-definido). Chegamos à conclusão de que o fenômeno em tela apresenta caráter altamente sistêmico, ou seja, sua variação é governada sobretudo por fatores linguísticos, que sinalizam peculiaridades do falar popular fortalezense.

Palavras-chave: Estratégias de relativização. Sociolinguística Variacionista. Falar popular. NORPOFOR. Fortaleza-CE.

\section{ABSTRACT}

Based on the theoretical-methodological assumptions of Variationist Sociolinguistics, this study aims to analyze the variation of relativization strategies in the popular speech of the city of Fortaleza-CE. The transmitted data were extracted from the speech of 54 informants in sociolinguistic descriptions of the DID type (Dialogue between Informant and Documenter), belonging to the database of the Projeto Norma Oral do Português Popular de Fortaleza (NORPOFOR). In our sample, we found a total of 883 occurrences of relative sentences, with the cutter relativization strategy standing out compared to the standard strategy. For the cutting strategy, the beneficiary variables were a syntactic function of the relative pronoun (relative complement and adverbial adjunct), type of relative sentence (restrictive), preposition governed by the verb/name ("in" and "with") and semantic feature \pm defined from the antecedent (-defined). We came to the conclusion that the phenomenon on screen has a highly systemic character, that is, its variation is governed mainly by linguistic factors, that signal peculiarities of popular Fortaleza speech.

Keywords: Relativization strategies. Variationist Sociolinguistics. Popular speech. NORPOFOR. Fortaleza-CE.

\section{Introdução}

Se é comum diversos aspectos na vida do ser humano estarem sujeitos a variações e modificações por motivos diversos, com a língua(gem) não acontece de forma diferente. Nesse âmbito, a atenção à instância da variação linguística deve-se ao fato de que diversos fatores linguísticos e extralinguísticos influenciam a maneira de falar dos usuários de uma língua e também no modo como os falantes avaliam e percebem a língua em seus usos.

$\mathrm{Na}$ vasta seara dos usos linguísticos, encontramos inúmeros fenômenos variáveis, que abarcam todos os níveis de análise linguística: 
lexical, fonético-fonológico, morfológico, sintático, semântico e discursivo. Para o presente artigo, elegemos como tema as estratégias de relativização (orações relativas) de contexto preposicionado sob a perspectiva variacionista, fenômeno de natureza sintática, que analisaremos com base em ocorrências de amostra do banco de dados Projeto Norma Oral Popular de Fortaleza (doravante, NORPOFOR).

O fenômeno da relativização é bastante frequente nas línguas naturais, uma vez que está diretamente ligado ao fato de, em nossas interações humanas, estarmos recorrentemente fazendo a reativação dos referentes que construímos na fala e na escrita, isto é, fazendo menção aos termos que já empregamos em uma dada comunicação, a fim de evitarmos repetições e sermos efetivos nos sentidos que queremos expressar. Essa capacidade de fazermos remissões a termos que já enunciamos nas cadeias comunicativas que empreendemos denomina-se referenciação e está inserida na nossa competência comunicativa, a qual consiste na capacidade de o indivíduo lançar mão de sua língua- -alvo de maneira adequada/apropriada, norteando-se pelos distintos e variados contextos da comunicação humana (HYMES, 1995). Logo, a referenciação é um recurso discursivo que pode se manifestar por meio de mecanismos "[...] de ordem 'gramatical' - pronomes pessoais de terceira pessoa (retos e oblíquos) e os demais pronomes (possessivos, demonstrativos, indefinidos, interrogativos, relativos)" (KOCH, 2016, p. 46), além de outros mecanismos linguísticos. Como podemos notar pelo que diz Koch (2016), a referenciação pode ser construída com os pronomes relativos, ou seja, as orações relativas também são um meio de fazer remissões na comunicação. No que se refere à variação linguística dessas orações, o português brasileiro (doravante, $\mathrm{PB}$ ) dispõe de três estratégias de relativização, ilustradas a seguir:

I. O seguro de saúde deveria incluir até o remédio de que a pessoa precisa.

II. O seguro de saúde deveria incluir até o remédio que a pessoa precisa dele. 
III. O seguro de saúde deveria incluir até o remédio que a pessoa precisa. $^{1}$

No caso das ocorrências acima, temos três maneiras distintas de estruturar a oração relativa para transmitir uma mesma informação: em I, temos a estratégia padrão, evidenciada pelos gramáticos normativos, conforme podemos visualizar a regência verbal, sendo obedecida a partir do uso da preposição; em II, temos a estratégia não padrão denominada de copiadora haja vista o termo já relativizado (remédio) pelo pronome relativo (que) ser copiado na oração subordinada por um pronome (dele), chamado de pronome lembrete ou pronome cópia; e em III, temos a estratégia não padrão conhecida por cortadora, amplamente utilizada no $\mathrm{PB}$, na qual há a omissão da preposição regida pelo verbo, sem acréscimo de pronome cópia.

Não obstante o respaldo desse fenômeno tenha sido evidenciado por várias pesquisas no Brasil que o tomaram por objeto de estudo, inclusive na investigação de Pinheiro (1998) com a variedade culta de Fortaleza, identificamos uma lacuna a ser preenchida: nenhum estudo foi realizado acerca das estratégias de relativização na variedade popular da capital cearense. Isso nos direciona a apontar que o quadro sociolinguístico do fenômeno em questão ainda não foi completamente investigado, uma vez que Fortaleza possui diferentes variedades linguísticas, e, destas, a pesquisa já realizada só abrangeu a dos informantes cultos (graduados).

Desse modo, o nosso objetivo, no presente artigo, é analisar a influência dos condicionadores linguísticos e sociais sobre a variação das estratégias de relativização padrão e cortadora na fala popular fortalezense, com base nos postulados da Sociolinguística Variacionista. A fim de cumprirmos

1 Essa ocorrência de oração relativa cortadora foi retirada do inquérito $\mathrm{n}^{\mathrm{o}} 62$ do NORPOFOR, o corpus de nossa pesquisa. Os outros dois exemplos foram elaborados a partir deste, a fim de explicarmos a variação do fenômeno com uma mesma sentença relativa. Ao longo deste artigo, nas ocorrências trazidas como exemplos, as orações relativas serão marcadas em itálico, a fim de que sejam mais bem visualizadas pelo leitor.

Confluência. Rio de Janeiro: Liceu Literário Português, n. 61, p. 185-225, jul.-dez. 2021 
esse objetivo, levantamos nossa questão geral de pesquisa, a saber: como se manifesta o comportamento variável das estratégias de relativização no português popular de Fortaleza quanto aos condicionadores linguísticos, aos condicionadores sociais e aos aspectos da mudança linguística?

O tom diferencial deste estudo está em ele se debruçar sobre uma temática que não é abordada há mais de 20 anos em Fortaleza-CE e que ainda não foi estudada no português popular da referida capital, tendo em vista que o estudo já realizado - o de Pinheiro (1998) - se deu com a análise da fala culta. Dessa forma, esta investigação se unirá aos demais estudos que contemplam outros fenômenos variáveis, numa busca de contribuir para o conhecimento das especificidades do português falado em Fortaleza-CE.

Quanto à organização retórica, o presente artigo é constituído de quatro seções, afora esta introdução e as considerações finais. Na primeira seção, trazemos alguns postulados da Teoria da Variação e Mudança Linguística. Na segunda, descrevemos a revisão de literatura dos estudos variacionistas que contemplaram o fenômeno da relativização no $\mathrm{PB}$. Na terceira seção, apresentamos os aspectos metodológicos de nossa pesquisa. Na quarta, discutimos e analisamos os nossos resultados.

\section{Os aspectos teóricos da Sociolinguística Variacionista}

É identitário das línguas naturais o fato de elas serem passíveis de variação e mudança, no entanto essa concepção, embora bastante presente e difundida atualmente, nem sempre foi aceita no universo dos estudos linguísticos, principalmente pelas correntes estruturalistas da linguística.

O fato é que, com a instauração da linguística moderna, inaugurada por Ferdinand de Saussure em seu Curso de Linguística Geral (1916), os estudos linguísticos passaram a ter um estatuto científico. Contudo, no início da linguística moderna, não obstante a vertente saussuriana reconhecesse o caráter social da língua, não o priorizaram, e, desse modo, os estudos na área voltaram-se eminentemente para as estruturas internas e imanentes da 
língua, conforme podemos notar assertivamente na própria obra seminal de Saussure: "Nossa definição de língua supõe que eliminemos dela tudo o que lhe seja estranho ao organismo, ao seu sistema, numa palavra: tudo quanto se designa pelo termo 'linguística externa'.” (SAUSSURE, 2006, p. 29). Logo, na vertente estruturalista, a língua é preconizada como uma estrutura autônoma e homogênea, ou seja, não dependente de fatores externos e analisada apenas em sua natureza intrinsecamente linguística.

Vale ressaltar que esse estudo de caráter homogêneo perdurou no decorrer do século XX, e uma outra teoria que apregoava a importância somente do aspecto imanente da língua foi o gerativismo, cujo linguista emblemático foi Noam Chomsky, que preconizou a língua como sistema de princípios universais baseada na faculdade humana da linguagem (conhecimento da língua que o falante possui em sua mente).

De encontro às concepções estruturalista e gerativista de língua, ganharam saliência, a partir da década de 1960, os estudos de William Labov, cuja marca central é a presença dos fatores sociais na análise linguística e a consideração do aspecto heterogêneo da língua. Com esse respaldo teórico, o estatuto da sociolinguística passa a ser mais bem delineado, apresentando solidez, para que o caráter variável e mutável das línguas possa ser investigado de maneira sistemática e empírica. Assim, os estudos de Labov (2008) e Weinreich, Labov e Herzog (2006) implementaram a Teoria da Variação e Mudança Linguística, a qual também é conhecida por Sociolinguística Variacionista, cujo modelo teórico-metodológico até hoje é um profícuo aporte para as pesquisas acerca dos fenômenos variáveis das línguas naturais em várias partes do mundo. É da competência dessa teoria mostrar e explicar os fenômenos que estão em variação na língua, evidenciando o quanto esta é dinâmica e motivada não só por fatores que lhe são intrínsecos (estruturais), mas também externos (sociais).

É fundamental considerarmos que Labov desenhou o arcabouço teórico-metodológico da Sociolinguística Variacionista por meio das pesquisas que ele próprio desenvolveu. Um dos seus primeiros estudos foi realizado em 
1963 na ilha de Martha's Vineyard, em Massachusetts, nos Estados Unidos, com a investigação da variação fonética entre os ditongos /ay/ e /aw/, com base em estratificação por regiões, faixas etárias, grupos profissionais e etnias desse espaço peninsular norte-americano, visando à reconstrução histórica desse caso de mudança sonora. Outro importante estudo laboviano versou sobre a estratificação do /r/ pós-vocálico nas lojas de departamentos em Nova York. Labov observou duas formas de pronúncia desse segmento fonológico: realização ou apagamento em contextos fonológicos idênticos, seja em posição final (car) ou interior (cart) à palavra. A começar desses trabalhos, Labov foi comprovando empiricamente o seu argumento de que "correlacionandose o complexo padrão linguístico com diferenças concomitantes na estrutura social, será possível isolar os fatores sociais que incidem diretamente sobre o processo linguístico" (LABOV, 2008, p. 19).

Um dos postulados basilares da Teoria da Variação e Mudança Linguística - e um pré-requisito para a compreensão dos demais - é o da heterogeneidade ordenada (LABOV, 2008). Esse axioma rompe com as considerações, durante muito tempo defendidas pelos estruturalistas e gerativistas, de que a língua é um sistema homogêneo, o qual deixa em segundo plano o caráter variável e mutável da língua. Faraco (2006), ao fazer as notas introdutórias dos Fundamentos empíricos para uma Teoria da Mudança Linguística, um dos clássicos de Labov, pontua bem sobre esse rompimento:

\footnotetext{
Propõem, então, que o axioma da homogeneidade seja abandonado, instaurando-se em seu lugar o axioma da heterogeneidade ordenada. Buscam--se caminhos teóricos para harmonizar os fatos da heterogeneidade (a língua como uma realidade inerentemente variável) com a abordagem estrutural (língua como uma realidade inerentemente ordenada). (FARACO, 2006, p. 13).
}

Com a instauração desse axioma, o caráter sistemático da língua deixa de ser atribuído somente para o que nela é categórico, aplicando-se também ao que é variável. Destarte, quebra-se o paradigma de que sistematicidade diz 
respeito somente ao que é homogêneo, uma vez que construções heterogêneas na língua têm o seu teor de estruturalidade. Isso implica deixar de considerar que variabilidade e sistematicidade são aspectos linguísticos excludentes entre si. Para atestar e ancorar essas rupturas com as ideias estruturalistas, Labov propõe um modelo teórico-metodológico que trata sistematicamente a variação e a mudança, as quais podem ser detectadas na fala ou vernáculo das pessoas. $\mathrm{O}$ instrumental de reflexão e análise laboviano escolhe como objeto os fenômenos variáveis e mutáveis por considerá-los manifestações linguísticas naturais, uma vez que, provenientes do vernáculo, refletem a língua em seu caráter vivo.

Para a análise sociolinguística, cabe lançarmos mão de alguns conceitos que acompanham o aparato de descrição linguística proposto por Labov (2008), a saber: variação, variantes, variável e variedade. A variação concerne ao processo de uma língua apresentar formas alternativas ou concorrentes de dizer uma mesma coisa com mesmo significado representacional; essas formas são denominadas de variantes, que consistem em "expressões que se referem ao mesmo estado de coisas, [apresentando] o mesmo valor de verdade"2 (LABOV, 1978, p. 7, tradução nossa). A variável, por seu turno, corresponde a um aspecto da estrutura linguística que sofre variação ordenada dentro do sistema linguístico (LABOV, 2006; WEINREICH; LABOV; HERZOG, 2006); em outras palavras, a variável é o fenômeno gramatical no qual ocorre variação. Além dessa acepção, o termo variável concerne aos fatores linguísticos e sociais que determinam a variação e mudança linguística, conferindo-lhes sistematicidade (WEINREICH, LABOV; HERZOG, 2006). Por último, a variedade corresponde ao vernáculo específico de um determinado grupo de falantes (LABOV, 2006), podendo ser definida por critérios sociais, regionais, culturais, ocupacionais, entre outros.

2 No original: "[...] utterances that refer to the same state of affairs have the same truthvalue $[\ldots] "$ 
Aproveitamos o ensejo dessa definição de variedade para pontuarmos que a Sociolinguística Variacionista, por tomar como objeto de estudo o vernáculo, explora não o que é falado ou intuído por indivíduos isoladamente, o que Labov define como idioleto, mas sim as comunidades de fala, que detêm dialetos ou variedades, constituindo o locus para a investigação de fenômenos linguísticos variáveis e definindo-se como grupos de falantes que "compartilham um conjunto comum de padrões normativos, mesmo quando encontramos uma variação altamente estratificada na fala real" (LABOV, 2008, p. 225). Nesse sentido, Labov toma nota de que os "indivíduos não são as unidades finais da análise linguística, mas os componentes que são usados para construir modelos de nosso objeto de interesse primário, a comunidade de fala" (LABOV, 1994, p. 72, tradução nossa) ${ }^{3}$. Ressaltamos, além do mais, que a comunidade de fala, além de apresentar as mesmas normas e atitudes ante a linguagem, pode ser identificada com base em mais dois outros critérios: compartilhamento de traços linguísticos distintos de outros grupos por parte dos falantes; elevada frequência de comunicação entre os membros da comunidade (GUY, 2000).

Em termos de exemplos para esses conceitos que explanamos, tomemos o que aborda a proposta de nosso estudo: as estratégias de relativização constituem a nossa variável, cujas variantes são as orações relativas padrão e cortadora, a serem investigadas na variedade do português popular de Fortaleza.

Após termos discorrido brevemente sobre algumas premissas teóricas da Sociolinguística Variacionista, partamos para a próxima seção, onde apresentaremos alguns estudos de égide variacionista que versaram sobre as estratégias de relativização.

3 No original: “[...] individuos no son las unidades finales del análisis linguístico, sino los componentes que se emplean para construir modelos de nuestro objeto de interes primário, la comunidad de habla." 


\section{Revisão de literatura sobre a variação entre as relativas cortadoras e padrão no PB}

A temática das estratégias de relativização suscita muitos estudos sob as diferentes perspectivas linguísticas: formalismo, funcionalismo, aquisição da linguagem e variacionismo. Desse modo, percebemos que a relativização se configura como um campo fértil para as investigações linguísticas. Para a consecução do nosso objetivo com este artigo, nosso foco será apenas nos estudos que, como o nosso, investigaram o fenômeno à luz da Teoria da Variação e Mudança Linguística e, destes, resenharemos, nesta seção, apenas teses e dissertações cujos materiais de análises foram bancos de dados sociolinguísticos.

O pioneirismo na investigação desse fenômeno no Brasil deve-se a Mollica (1977), autora que pesquisou as orações relativas em entrevistas realizadas com quatro informantes cariocas nativos, de classe social baixa e semiescolarizados, participantes do Movimento Brasileiro de Alfabetização (MOBRAL). Sendo assim, a autora não investigou variáveis sociais, devido à impossibilidade de estratificação em gênero, faixa etária e grau de escolaridade. Em termos gerais, Mollica (1977) identificou 1299 ocorrências de cláusulas relativas, das quais 1195 (92\%) aplicaram a regra do apagamento da cópia, ou seja, correspondiam às orações do tipo padrão de sujeito e objeto direto e às não padrão cortadoras ${ }^{4}$. Para a rodada com as relativas de sintagmas de complementos preposicionados, os resultados favorecedores da relativa cortadora foram: ausência de elementos intervenientes (96,3\% e PR 0.72); traço não humano do antecedente $(94,5 \%$ e PR 0.68); traço +especificado do antecedente (96,4\% e PR 0.65); traço + coletivo do antecedente $(95,8 \%$ e PR 0.65$)$.

4 Em seu estudo, Mollica (1977), para configurar o apagamento do pronome cópia, uniu as relativas padrão de sujeito e objeto direto (não preposicionadas) e as não padrão cortadoras (preposicionadas) com a etiqueta de "cortadoras", o que não permite separálas no percentual de apagamento. 
Um outro estudo pioneiro deste tema foi o de Tarallo (1983), que investigou sincronicamente dois tipos de material: entrevistas sociolinguísticas de 40 informantes da cidade de São Paulo estratificados por sexo, faixa etária, escolaridade e classe social; e dados das mídias televisivas analisados a partir do grau de formalidade. O corpus diacrônico, por sua vez, constituise de cartas e textos teatrais escritos por brasileiros ao longo dos séculos XVIII e XIX. Tarallo (1983) coletou 2750 ocorrências de orações relativas na investigação sincrônica (1700 das entrevistas sociolinguísticas e 1050 dos gêneros midiáticos orais) e 1579 dados na investigação diacrônica, perfazendo um total de 4.329 orações relativas coletadas e submetidas ao tratamento do programa estatístico. A variável dependente consistiu na presença/ausência do pronome cópia, sendo as três estratégias de relativização as variantes (copiadora, cortadora, padrão). Em termos gerais, os resultados forneceram as frequências de $9,5 \%$ para a relativa copiadora, $14,9 \%$ para a relativa cortadora e $75,6 \%$ para as relativas padrão. Os resultados específicos apontaram que a relativa copiadora é favorecida pelos traços semânticos +humano (13,9\% e PR 0.66), +indefinido (11,3\% e PR 0.51) e +singular (11,2\% e PR 0.66) do termo antecedente, pelas funções sintáticas de objeto indireto (21,1\% e PR 0.65) e genitivo (52,9\% e PR 0.81) para o termo relativizado, pela posição à direita $(10,5 \%$ e PR 0.53$)$ em relação à oração principal, pela presença de elementos intervenientes (41,7\% e PR 0.83$)$ entre a oração relativa e a principal e pelo tipo de oração não restritiva (16,4\% e PR 0.70$)$. $\mathrm{O}$ autor chegou à conclusão de que a estratégia cortadora vem aumentando na preferência linguística dos brasileiros quando estes empregam a relativização.

O estudo de Kato et al. (1996) investigou, em dados do projeto Norma Urbana Culta (NURC), a presença ou ausência de preposição seguindo o pronome relativo de sintagmas com ambiência preposicionada. As autoras constataram apenas 43 orações com preposição num universo de 123 oportunidades de uso, o que consideraram como baixo perante o fato de todos os informantes do corpus serem graduados. Os grupos de fatores considerados relevantes e favorecedores do uso da preposição foram função 
sintática de adjunto adverbial para o pronome relativo ( $49 \%$ e PR 0.69), tipo de entrevista formal (56\% e PR 0.70) e ocorrência de preposições diferentes para o antecedente e para a oração relativa (50\% e PR 0.75). Assim, nesse estudo, os condicionadores linguísticos foram mais importantes que os extralinguísticos.

Já Pinheiro (1998), a partir de dados do Português Oral Culto de Fortaleza (PORCUFORT), analisou as relativas em contextos de sintagmas preposicionados, adotando como variável dependente as relativas padrão e cortadora. Os resultados gerais revelaram que, de um total de 325 ocorrências de orações relativas de sintagmas preposicionais, $40 \%$ foram padrão, e $60 \%$, cortadoras. Os resultados para as variáveis evidenciaram que a função de adjunto adverbial (52\% e PR 0.64), as elocuções formais (67\% e PR 0.76), o sexo masculino ( $47 \%$ e PR 0.58) e a informação nova ( $46 \%$ e PR 0.57 ) são os fatores que favorecem o uso da relativa padrão. $\mathrm{O}$ autor apontou que $\mathrm{o}$ fenômeno no falar culto de Fortaleza é um caso de variação estável.

Corrêa (1998) investigou as relativas em dados do NURC para os informantes cultos em cinco capitais brasileiras e depois apenas para São Paulo. Para as cinco capitais, foram identificadas 123 ocorrências de relativas de contexto preposicionado ( $35 \%$ do tipo padrão e $65 \%$ do tipo vernacular ${ }^{5}$ ), e os grupos de fatores apontados como relevantes pelo programa estatístico para o favorecimento da relativa padrão foram: função sintática do termo relativizado, com ênfase no adjunto adverbial (49\% e PR 0.81); preposições diferentes requeridas pelo antecedente e pelo pronome relativo (57\% e PR 0.75); local da entrevista, sobretudo Recife (69\% e PR 0.97); tipo de inquérito elocução formal (56\% e PR 0.76). Averiguando apenas a fala culta de São Paulo, foram identificadas 255 cláusulas relativas de contexto preposicionado $(55 \%$ do tipo padrão e $45 \%$ do tipo vernacular), e os grupos de fatores considerados relevantes no favorecimento da relativa padrão foram: função sintática do termo relativizado, mormente o adjunto adverbial (61\% e PR 0.63); preposições

5 Oração relativa do tipo vernacular, no tratamento terminológico da autora, diz respeito à junção das estratégias cortadora e copiadora. 
diferentes para a relativa e para o antecedente (58\% e PR 0.57); faixa etária dos informantes com mais de 55 anos (79\% e PR 0.85); as profissões do grupo 1, que engloba advogados, professores e escriturários (68\% e PR 0.63); sexo masculino (57\% e PR 0.60); e tipo de inquérito elocução formal $(80 \%$ e PR 0.66). A autora concluiu que o fenômeno se trata de uma variação estável.

O trabalho de Barros (2000), por sua vez, versou sobre as relativas no português falado por nativos em João Pessoa, a partir de dados de uma amostra do projeto Variação Linguística no Estado da Paraíba (VALPB), composta por 60 informantes estratificados por sexo, idade e escolaridade. Os resultados gerais indicaram um total de 413 orações relativas, sendo 52 (12,6\%) copiadoras, 164 (39,7\%) padrão e 197 (47,7\%) cortadoras. Na segunda rodada, por considerar apenas as orações relativas não padrão em contexto preposicionado, a autora constatou 215 estratégias relativas (193 cortadoras e 22 copiadoras). Os grupos de fatores considerados relevantes para a aplicação da regra foram: animacidade do antecedente, com o traço -humano (99\% e PR 0.81); especificidade do antecedente, com o traço +específico (92\% e PR 0.58); e distância zero entre o termo relativizado e o relativizador $(95 \%$ e PR 0.70). A pesquisa sinalizou um caso de variação estável.

Em seguida, Burgos (2003) empreendeu uma investigação acerca das estratégias de relativização em Helvécia, comunidade rural da Bahia composta por descendentes afro-brasileiros, representados pelos dados do projeto Vertentes do Português rural da Região da Bahia e Sergipe, extraindo deste uma amostra de 18 informantes, estratificados por faixa etária e por sexo. Os resultados gerais indicaram um total de 569 orações relativas, divididas em 366 do tipo padrão, 185 do tipo cortadora e 18 do tipo copiadora. Na primeira rodada, os fatores considerados como relevantes no favorecimento da relativa copiadora foram o tipo de oração não restritiva (10\% e PR 0.78$)$ e a presença de elementos intervenientes entre a relativa e o termo antecedente ( $6 \%$ e PR 0.68). Já na segunda rodada, as variáveis apontadas pelo programa como relevantes no favorecimento da relativa copiadora foram a função sintática de genitivo para o pronome relativo (13\% 
e PR 0.61) e o traço semântico thumano do antecedente (50\% e PR 0.89). O estudo sinalizou um caso de variação estável.

Silva (2011) analisou as estratégias de relativização em uma amostra com 21 informantes extraída do projeto Descrição Sócio-Histórica do Português de Belo Horizonte. Os resultados gerais foram 284 ocorrências para as variantes padrão (82\%), 49 para as cortadoras (14\%) e 13 para as copiadoras (4\%). Na rodada padrão vs. cortadora, os fatores considerados relevantes para o favorecimento da cortadora foram: as funções sintáticas não oblíquas (21\% e PR 0.79); a posição periférica da lacuna na relativa (39\% e PR 0.97); a existencialidade da oração principal (19\% e PR 0.76); e o traço singular do termo antecedente ( $18 \%$ e PR 0.59 ).

O trabalho de Ramos (2015) descreveu as estratégias de relativização no português de Belo Horizonte, também a partir de dados do projeto Descrição Sócio-Histórica do Português de Belo Horizonte. A amostra foi composta por 24 informantes. A aplicação da regra adotada foi para as estratégias não padrão. Os resultados gerais apontaram 394 ocorrências de relativas, sendo $21 \%$ não padrão e $79 \%$ padrão. Na segunda rodada, padrão $v s$. cortadora (a que interessa para o nosso estudo), foram relevantes os seguintes fatores para o favorecimento da cortadora: funções de objeto indireto (96\% e PR 0.99) e de complementos/adjuntos (62\% e PR 0.99) para o pronome relativo; faixas etárias dos 23 aos 59 anos (19\% e PR 0.77) e até os 22 anos (21\% e PR 0.72); escolaridade básica (22\% e PR 0.71).

O trabalho mais recente, o de Silva (2018), também analisou as orações relativas no português falado em Feira de Santana (BA), a partir de dados de 24 entrevistas sociolinguísticas do tipo DID extraídas do projeto A Língua Portuguesa do Semiárido Baiano (Fase 3). Essas entrevistas se subdividiram em duas amostras: norma popular (12 informantes analfabetos ou pouco escolarizados) e norma culta (12 informantes graduados). Os resultados gerais apontaram 1248 orações relativas, sendo 932 não preposicionadas e 316 preposicionadas; no primeiro grupo, o resultado foi semicategórico para as relativas padrão (98\%), então a discussão sobre efeitos variáveis voltou-se 
apenas para as preposicionadas ( $13 \%$ padrão, $84 \%$ cortadoras e $3 \%$ copiadoras). Os grupos de fatores apontados como relevantes para o beneficiamento da cortadora foram: os valores semânticos lugar (34\% e PR 0.68) e coisa (32\% e PR 0.67) para o termo antecedente; a faixa etária dos 25 aos 35 anos (27\%); o sexo masculino (22\%); e a escolaridade baixa ou inexistente (23\%). A autora concluiu que, assim como estudos anteriores evidenciaram, há o uso majoritário das relativas cortadoras no falar popular e culto feirense. A autora apontou que o fenômeno na variedade analisada se enquadra como um caso de mudança em progresso.

Com base nos trabalhos recém-resenhados, é mister elucidarmos as hipóteses relacionadas às duas variantes, cuja concorrência variável será o foco de nossa análise. Levantamos como hipóteses para o favorecimento da variante cortadora: os traços semânticos -humano, +definido e -singular do antecedente; a função sintática de objeto indireto para o pronome relativo; a ausência de elementos intervenientes entre a oração relativa e o termo relativizado; a informação dada para o status informacional do antecedente; o requerimento de preposições iguais por parte do antecedente e do pronome relativo; a posição da oração relativa encaixada em relação à oração principal; a oração restritiva; as preposições por, de, com e a regidas pelo verbo/ nome; o sexo feminino; todas as faixas etárias, sobretudo os mais jovens; os informantes menos escolarizados.

Já para a realização da oração relativa padrão, por sua vez, hipotetizamos que os seguintes fatores a beneficiam: a função sintática de adjunto adverbial para o pronome relativo; a informação nova para o status informacional do antecedente; o requerimento de preposições diferentes por parte do antecedente e do pronome relativo; a posição da oração relativa à direita em relação à oração principal; a oração restritiva; a preposição em regida pelo verbo/nome; o sexo masculino; os informantes mais escolarizados.

Apresentada a nossa revisão de literatura e, com base nela, levantadas as hipóteses para a nossa análise, delineamos, na próxima seção, a nossa metodologia. 


\section{Metodologia}

\subsection{Corpus, amostra e ética da pesquisa}

Como corpus para esta pesquisa, escolhemos o NORPOFOR, banco de dados sociolinguísticos cujos inquéritos foram colhidos de 2003 a 2006, abrangendo informantes de vários bairros da capital cearense. O referido banco de dados é formado por um total de 196 informantes, distribuídos de acordo com o sexo (masculino e feminino), a faixa etária (I- 15 a 25 anos, II- 26 a 49 anos e III- 50 anos em diante), a escolaridade (A- 0 a 4 anos, B- 5 a 8 anos e C- 9 a 11 anos de estudo) e o tipo de inquérito (Diálogo entre Informante e Documentador - DID, Diálogo entre dois Informantes - D2 e Elocução Formal - EF). Essa estratificação pode ser visualizada no quadro 1, a seguir.

Quadro 1. Distribuição dos informantes do NORPOFOR por sexo, faixa etária, escolaridade e tipo de registro

\begin{tabular}{|c|c|c|c|c|c|c|c|c|c|c|c|c|c|c|c|c|c|c|}
\hline \multirow{4}{*}{$\begin{array}{c}\text { Registro } \\
\text { Escolaridade } \\
\text { Faixa Etária }\end{array}$} & \multicolumn{18}{|c|}{ Sexo } \\
\hline & \multicolumn{9}{|c|}{ Homem } & \multicolumn{9}{|c|}{ Mulher } \\
\hline & \multicolumn{3}{|c|}{ DID } & \multicolumn{3}{|c|}{ D2 } & \multicolumn{3}{|c|}{ EF } & \multicolumn{3}{|c|}{ DID } & \multicolumn{3}{|c|}{ D2 } & \multicolumn{3}{|c|}{ EF } \\
\hline & $0-4$ & $5-8$ & $9-11$ & $0-4$ & $5-8$ & $9-11$ & $0-4$ & $5-8$ & $9-11$ & $0-4$ & $5-8$ & $9-11$ & $0-4$ & $5-8$ & 9-11 & $0-4$ & $5-8$ & $9-11$ \\
\hline 15 a 25 anos & 5 & 4 & 5 & 4 & 4 & 5 & 2 & 2 & 4 & 4 & 5 & 4 & 2 & 5 & 5 & 0 & 0 & 2 \\
\hline 26 a 49 anos & 4 & 5 & 5 & 4 & 4 & 4 & 4 & 2 & 4 & 5 & 5 & 5 & 4 & 5 & 5 & 0 & 5 & 3 \\
\hline 50 em diante & 5 & 6 & 5 & 3 & 3 & 4 & 3 & 2 & 1 & 4 & 5 & 4 & 4 & 5 & 4 & 1 & 1 & 1 \\
\hline \multirow[t]{4}{*}{ Total } & 14 & 15 & 15 & 11 & 11 & 13 & 09 & 06 & 09 & 13 & 15 & 13 & 10 & 15 & 14 & 01 & 06 & 06 \\
\hline & \multicolumn{3}{|c|}{44} & \multicolumn{3}{|c|}{35} & \multicolumn{3}{|c|}{24} & \multicolumn{3}{|c|}{41} & \multicolumn{3}{|c|}{39} & \multicolumn{3}{|c|}{13} \\
\hline & \multicolumn{9}{|c|}{103} & \multicolumn{9}{|c|}{93} \\
\hline & \multicolumn{18}{|c|}{196} \\
\hline
\end{tabular}

Fonte: Araújo, Viana e Pereira (2018, p. 22). 
Ressaltamos que, visando não permitir a interferência das variedades de outras regiões (ARAÚJO, 2011), os 196 informantes do NORPOFOR foram selecionados a partir dos seguintes critérios: deveriam ser todos nascidos em Fortaleza ou terem vindo morar nessa cidade com 5 anos de idade, no máximo; deveriam ser filhos de pais cearenses; não poderiam ter se ausentado de Fortaleza por mais de dois anos consecutivos; deveriam possuir moradia fixa em Fortaleza (ARAÚJO; VIANA; PEREIRA, 2018). Para a presente análise, extraímos, do referido corpus, nossa amostra, explanada no quadro 2, a seguir.

Quadro 2. Amostra de análise com a estratificação dos informantes do NORPOFOR por variáveis sociais controladas em nosso estudo

\begin{tabular}{|c|c|c|c|c|c|c|}
\hline \multirow[b]{3}{*}{ Faixa etária } & \multicolumn{6}{|c|}{ Sexo } \\
\hline & \multicolumn{3}{|c|}{ Masculino } & \multicolumn{3}{|c|}{ Feminino } \\
\hline & $\begin{array}{c}\text { A } \\
0-4 \text { anos }\end{array}$ & $\begin{array}{c}\text { B } \\
5-8 \text { anos }\end{array}$ & $\begin{array}{c}C \\
9-11 \\
\text { anos }\end{array}$ & $\begin{array}{c}\text { A } \\
\text { 0-4 anos }\end{array}$ & $\begin{array}{c}\text { B } \\
5-8 \text { anos }\end{array}$ & $\begin{array}{c}C \\
9-11 \\
\text { anos }\end{array}$ \\
\hline I- 15 a 25 anos & 3 & 3 & 3 & 3 & 3 & 3 \\
\hline II- 26 a 49 anos & 3 & 3 & 3 & 3 & 3 & 3 \\
\hline $\begin{array}{l}\text { III- a partir de } 50 \\
\text { anos }\end{array}$ & 3 & 3 & 3 & 3 & 3 & 3 \\
\hline TOTAL & \multicolumn{6}{|c|}{54 informantes } \\
\hline
\end{tabular}

Como podemos ver no quadro 2 , nossa amostra é composta por 54 informantes do tipo de registro DID, em cujas falas investigamos como se comporta a variação do fenômeno linguístico das estratégias de relativização. Descrevendo brevemente nossa amostra, temos 27 informantes do sexo masculino, distribuídos ainda em 9 para a faixa etária I com escolaridade A, 9 para a faixa II com escolaridade B, e 9 para a faixa III com escolaridade 
C; 27 do sexo feminino, estratificados ainda em 9 para a faixa etária I com escolarização A, 9 para a faixa II com escolarização B e 9 para a faixa III com escolarização C. Justificamos nossa opção pelo DID também devido ao seu grau intermediário de formalidade, diferentemente dos inquéritos do D2, que são os menos formais, e dos EF, que são os mais formais e monitorados.

Atestamos que, em atendimento aos princípios éticos da pesquisa científica, especificamente quando se lida com investigações envolvendo seres humanos, submetemos o projeto desta pesquisa ao Comitê de Ética em Pesquisa da Universidade Estadual do Ceará (CEP/UECE) e recebemos deste a liberação para realizarmos o presente estudo, conforme exara o nosso Certificado de Apresentação para Apreciação Ética (CAAE) de $n^{\circ}$ 27136819.6.0000.5534, sob o parecer consubstanciado de no 3.798.019. Assim, haja vista sua pertinência ética, a presente investigação sociolinguística tem garantida a sua legalidade científica.

\subsection{Envelope de variação, coleta de dados e programa estatístico utilizado}

Para a análise de nossos dados, a nossa variável dependente são as estratégias de relativização estruturadas em contexto de sintagmas preposicionais, sendo escolhidas para esse estudo as variantes padrão e cortadora.

As variáveis independentes - linguísticas e sociais - que controlamos neste estudo são: traços semânticos do antecedente \pm humano, \pm definido e \pm singular, função sintática do pronome relativo, função sintática do termo relativizado, distância entre o pronome relativo e o termo relativizado, estado de ativação do antecedente, preposição usada pelo antecedente e pelo pronome relativo, posição da relativa em relação à oração principal, tipo de oração relativa, preposição regida pelo verbo/nome, sexo, faixa etária e escolaridade.

Nosso primeiro contato com os dados foi a partir da leitura das transcrições dos inquéritos, a fim de os conhecermos (em especial os DID’s), 
o que nos permitiu extrairmos contextos mais completos das ocorrências do fenômeno, quando as coletamos por meio da ferramenta de busca localizar do programa Microsoft Word. À medida que fomos localizando, catalogamos todas as ocorrências de orações relativas em contexto preposicionado encontradas nos 54 inquéritos de nossa amostra de análise. Em seguida, empreendemos o processo de codificação dessas ocorrências, que consistiu em, com base no envelope de variação, fazer uma distribuição das variáveis por meio da escolha de símbolos para representá-las: números, letras, diacríticos, entre outros (MONTEIRO, 2000).

Porúltimo, submetemos os dados coletados ao programa computacional Goldvarb X, adaptação mais recente do VARBRUL para as configurações do Windows (SANKOF; TAGLIAMONTE; SMITH, 2005), uma vez que tem sido bastante utilizado entre os pesquisadores sociolinguistas, por incorporar “ [...] a ideia de que os processos linguísticos são influenciados simultaneamente por diversas variáveis independentes, tanto linguísticas quanto sociais" (GUY; ZILLES, 2007, p. 100). Esse programa aponta as variáveis relevantes para o favorecimento da variante elegida pelo pesquisador como aplicação da regra, isto é, aquela a partir da qual todos os resultados (percentagens e pesos relativos) serão gerados nas rodadas quantitativas (no caso deste estudo, a relativa cortadora), para interpretação sociolinguística. Na seção seguinte, analisaremos os resultados fornecidos por essa ferramenta estatística.

\section{Descrição e análise dos dados}

Chegamos ao momento de discutirmos a análise binária multivariada de nosso estudo, que consiste na rodada relativas cortadoras vs. relativas padrão. Para essa rodada, elegemos como aplicação da regra variável a estratégia de relativização cortadora, por ser a variante mais discutida no estado da arte, uma vez que ela é substancialmente empregada no PB em termos de relativização, em detrimento das outras variantes (KATO et al., 1996; PINHEIRO, 1998; BARROS, 2000; SILVA, 2018). 
As ocorrências para essa análise foram em número de 832, sendo 726 (87,3\%) para a estratégia cortadora e $106(12,7 \%)$ para a padrão, conforme mostra o gráfico 1 .

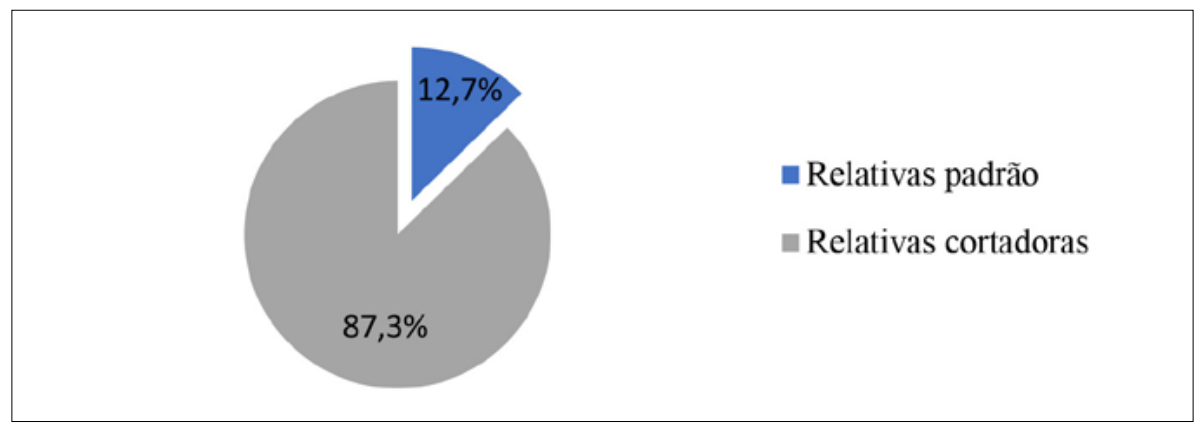

Gráfico 1. Frequências da rodada relativas cortadoras $v s$. relativas padrão

Conforme nos informam as frequências gerais do gráfico 1, podemos perceber que as orações relativas cortadoras lideram no emprego das estratégias de relativização presentes na fala popular fortalezense. Em nosso estado da arte, há duas pesquisas que também analisaram a concorrência variável entre as relativas cortadora e padrão, como mostra o gráfico 2 .

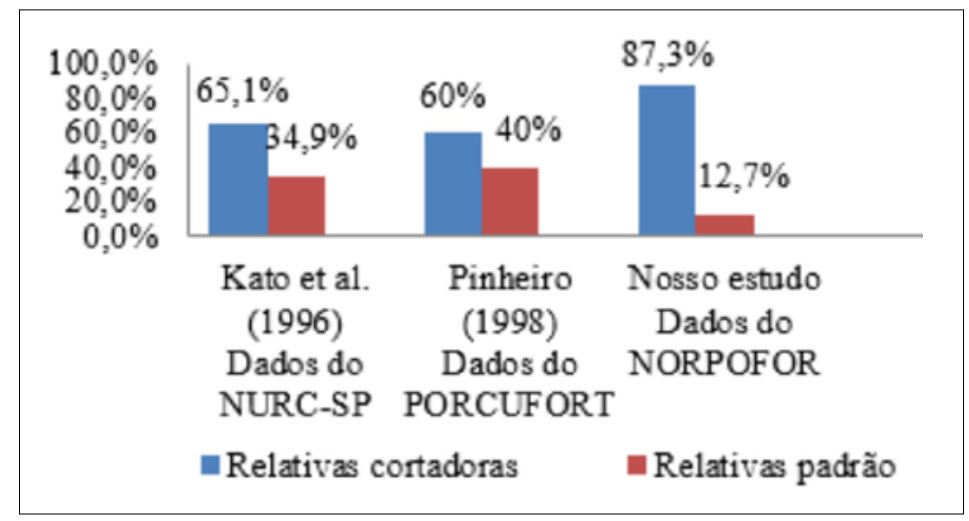

Gráfico 2. Frequências das variantes cortadora e padrão em estudos de nossa revisão de literatura e em nosso estudo

Confluência. Rio de Janeiro: Liceu Literário Português, n. 61, p. 185-225, jul.-dez. 2021 
As frequências expostas no gráfico 2, atinentes a trabalhos que analisaram a rodada relativas cortadoras vs. relativas padrão, mostramnos uma interessante constatação: a estratégia de relativização cortadora, inovadora no português falado, apresenta predomínio não só em nosso estudo, que investiga dados de fala popular, mas também nos estudos que abordaram a relativização na fala culta, como é o caso de Kato et al. (1996) e Pinheiro (1998), com percentuais próximos. Portanto, em se tratando especificamente do falar da capital cearense, no que diz respeito à relativização, podemos ver que o comportamento sociolinguístico dos falantes cultos e dos falantes não cultos - investigado por Pinheiro (1998) e pelo nosso estudo, respectivamente - é equiparável, não havendo polaridades por conta da natureza da comunidade de fala, uma vez que empregam preponderantemente a oração relativa cortadora.

Antes do processamento estatístico referente ao controle das variáveis independentes para a rodada variável, o programa Goldvarb X apresentou 6 nocautes ${ }^{6}$, sendo 3 no grupo de fatores função sintática do pronome relativo e 3 no grupo preposição regida pelo verbo/nome. Quanto ao primeiro grupo, os nocautes ocorreram com os fatores complemento nominal, adjunto adnominal e objeto indireto, com a manifestação de 11, 11 e 1 dados, nessa ordem, exclusivamente para a relativa cortadora. No segundo grupo, por sua vez, os nocautes manifestaram-se com as preposições por, para e $a$, com a ocorrência de 13, 24 e 17 dados, nessa sequência, também unicamente para a relativa cortadora. Resolvemos esses nocautes, desprezando-os, e partimos adiante com o processamento estatístico.

Após a leitura computacional, o Goldvarb X apontou 4 grupos de fatores como relevantes para o uso das relativas cortadoras no falar popular fortalezense; são eles, nesta ordem de prioridade: função sintática do pronome

6 Nocautes são as indicações de fatores ou grupos de fatores que se configuram como categóricos, ou seja, as variantes não competem com base nesses fatores ou grupos de fatores indicados. Os nocautes são apresentados justamente porque o programa estatístico só opera com dados variáveis. 
relativo, tipo de oração relativa, preposição regida pelo verbo/nome e traço semântico \pm definido do antecedente. Obviamente, o programa apontou como irrelevantes as demais variáveis testadas.

Nas subseções que seguem, discutiremos os resultados a partir do peso relativo (doravante PR) para cada um dos grupos de fatores selecionados estatisticamente como relevantes para o beneficiamento das estratégias de relativização cortadoras.

\subsection{Função sintática do pronome relativo}

Este grupo de fatores foi o primeiro selecionado como estatisticamente relevante para a aplicação da regra na rodada multivariada, o que reforça sua importância no condicionamento linguístico das orações relativas. Observemos, na tabela 1 seguinte, a atuação desse grupo de fatores em nossa amostra.

Tabela 1. Atuação da variável função sintática do pronome relativo sobre as relativas cortadoras (cortadoras vs. padrão)

\begin{tabular}{cccc}
\hline FATORES & Aplica/total & Percentual & PR \\
\hline Complemento relativo & $125 / 128$ & $97,7 \%$ & $\mathbf{0 . 6 5 2}$ \\
Adjunto adverbial & $449 / 518$ & $86,7 \%$ & $\mathbf{0 . 5 1 0}$ \\
Complemento circunstancial & $129 / 163$ & $79,1 \%$ & 0.349 \\
\hline
\end{tabular}

Percebemos, a partir da tabela 1, que as funções sintáticas de complemento relativo e adjunto adverbial para o pronome relativo privilegiam especificamente a estratégia de relativização cortadora, com os PR 0.652 e 0.510, respectivamente; o mesmo não acontece com o complemento circunstancial, que se mostrou com PR 0.373 para a aplicação da regra, desfavorecendo-a. 
Nossos resultados em relação à função sintática de adjunto adverbial para o pronome relativo contestam os resultados a que chegaram Kato et al. (1996) e Pinheiro (1998). Segundo esses pesquisadores, essa função sintática condiciona as estratégias de relativização padrão, e a explicação para isso está no fato de que adjuntos adverbiais são termos mais marginais na sentença, não tendo caráter argumental (de complementação), o que faz com que seu vínculo sentencial se dê por meio do auxílio da preposição, acarretando o uso da relativização padrão. No entanto, o resultado mostrado pela tabela 1 nos faz perceber que, no falar popular fortalezense, o adjunto adverbial favorece o emprego da relativa cortadora, dispensando, portanto, esse aspecto linguístico do estreitamento entre a oração relativa e o restante do período por meio da preposição.

Mesmo descartando essa necessidade de estreitamento sentencial da oração relativa via emprego da preposição, não podemos deixar de levar em conta a posição naturalmente marginal do adjunto adverbial na frase, aspecto que tem muito a nos dizer acerca da variação das estratégias de relativização no português popular fortalezense. A questão é que Labov (1994) preconiza que a variação linguística tem início pelas margens da sociedade e, a partir disso, podemos fazer uma paralelo, outrora já evidenciado por Coan e Carvalho (2016) ao investigar a relativização na escrita jurídica: a codificação linguística das formas inovadoras, em ambiência sintática, começa a sua manifestação também em posições mais marginais da sentença, ou seja, naqueles espaços sintáticos menos argumentais, preenchidos pelos adjuntos.

Cabe colocarmos, ainda, um ponto a respeito do adjunto adverbial, comparando sua atuação, que beneficia a relativa cortadora, com a do complemento circunstancial, que beneficia a relativa padrão, conforme podemos depreender da tabela 1 ao subtrairmos de 1 o PR 0,349 concernente a esse último fator. É interessante ponderarmos que tanto o adjunto adverbial quanto o complemento circunstancial têm valores adverbiais, porém com a diferença de o primeiro caracterizar-se por sua dispensabilidade (adjunção) à sentença, e o segundo por sua indispensabilidade (complementação) (ROCHA 
LIMA, 2011; CASTILHO, 2012). Aqui, convém voltarmos à questão postulada por Kato et al. (1996) e Pinheiro (1998) a respeito do estreitamento que o adjunto adverbial da oração relativa faz com o restante do período sintático por meio da preposição, favorecendo o emprego da relativização padrão. Nesse contexto, havíamos elucidado que, pelo nosso resultado, a norma oral popular de Fortaleza não leva em conta o referido estreitamento ao usar orações relativas preposicionadas cujos pronomes relativos exerçam a função de adjunto adverbial, uma vez que este beneficia a estratégia de relativização cortadora. Contudo, percebemos que, na mesma comunidade de fala, esse estreitamento sentencial a partir da preposição ocorre quando o pronome relativo assume função de complemento circunstancial (de valor adverbial), em virtude do caráter argumental deste, ou seja, de indispensabilidade para a compreensão da construção frásica que envolve a oração relativa; desse modo, essa função sintática privilegia, em nossos dados, a estratégia de relativização padrão. Vejamos as seguintes ocorrências de relativa cortadora e padrão extraídas de nossa amostra (os sublinhados indicam os termos que foram relativizados, que assumem funções sintáticas dentro da oração relativa, não necessariamente as mesmas assumidas na posição antecedente em que se encontram):

(1) perdi vários quilos eu nunca fui uma pessoa gorda né? mas na época assim eu fiquei assim realmente foi a época da minha vida que eu fiquei magro (NORPOFOR, DID, 150)

(2) éh:: por causa da da da do bairro em que eu morava né? eu morava num bairro como eu falei... pobre e:: me viciei logo em drogas e não dá pra você a::ssimilar as duas coisas drogas e estudo né? não dá de jeito nenhum jamais uma pessoa drogada ela consegue estudar... (NORPOFOR, DID, 150)

Na ocorrência 1, o processo de relativização nos permite perceber que a informação "a época da vida", que dentro da relativa (a partir do pronome relativo) assume função de adjunto adverbial, é acessória à construção 
verbal "fiquei magro" dita pelo informante, o que mostra a referida função beneficiando a oração relativa cortadora. Já na ocorrência 2, percebemos a forma verbal morava necessitar de uma complementação locativa, expressa no dado pelo sublinhado bairro, relativizado pelo pronome que acompanhado da preposição em, indicando a função sintática de complemento circunstancial (locativo) como favorecedora da estratégia de relativização padrão.

No que respeita ao complemento relativo, a sua atuação significativamente favorecedora sobre a estratégia cortadora reforça o caráter de novidade que esse resultado traz para a nossa investigação e, consequentemente, para o estado da arte desse fenômeno. Perante esse tom inovador, convencemo-nos de que não encontraríamos as explicações para sua relevância no cotejamento com outros estudos, e sim observando cautelosamente os dados de nossa amostra.

Um dos pontos que observamos, na amostra, para explicar linguisticamente essa atuação foi a influência da gramaticalização sobre a variação das relativas no falar popular fortalezense. A gramaticalização é classicamente concebida como a transformação de um item lexical em um elemento gramatical ou de um item gramatical em outro mais gramatical (FURTADO DA CUNHA; TAVARES, 2016). Trazendo para o escopo das estratégias de relativização, a gramaticalização consiste na transformação do pronome relativo que em conjunção integrante, perdendo seu caráter anafórico e assumindo apenas o aspecto de conector no período composto por subordinação. Isso nos faz entender ainda mais o elevado emprego da estratégia cortadora na norma popular fortalezense: como o relativo mais usado é o que, e ele vem perdendo suas propriedades anafóricas e convertendose em conector, o falante, ao usá-lo, não se utiliza da preposição e, portanto, tende a não relativizar termos com a estratégia padrão.

Ainda nesse ponto, precisamos considerar que o aspecto da gramaticalização acarreta usos linguísticos cristalizados, uma vez que itens gramaticais se destituem de algumas de suas propriedades, conforme mencionamos em referência ao pronome relativo que. E, em se tratando 
de variação linguística, o fato de variáveis linguísticas favorecem significativamente uma ou outra variante explica-se a partir da percepção desses usos cristalizados em uma comunidade de fala. Em relação ao fenômeno variável da relativização, o trabalho de Pinheiro (1998), com dados da fala culta em Fortaleza, identificou que as relativas padrão eram altamente favorecidas quando os pronomes relativos assumiam funções sintáticas de adjuntos adverbiais do tipo temporal ou locativo, cristalizadas principalmente na relativização com as expressões "no momento em que", "no trecho em que", "a parte onde", bastante fixadas no falar de fortalezenses graduados. Observando mais de perto os nossos dados, notamos que essa peculiaridade também ocorre entre os falantes da norma popular fortalezense, só que agora com as relativas cortadoras, quando os seus pronomes relativos apresentam a função sintática de complemento relativo, notadamente cristalizada quando os informantes operavam a relativização com os verbos falar (de) e gostar (de). Vejamos, a seguir, ocorrências que extraímos de nossa coleta para ilustrar essa particularidade no falar popular fortalezense:

(3) ... por exemplo essa parte da respiração que eu falei técnica é só com o tem::po ma::is né... que a pessoa vai vai se aprofundando e... o que foi mesmo que tu perguntou? (NORPOFOR, DID, 12)

(4) eu eu trabalhava lá na/ na casa dessa moça que eu te falei que trabalha no BEC... (NORPOFOR, DID, 16)

(5) e:: também o caratê era uma coisa que eu já gostava né... assim que eu assistia em fil::mes então eu gostava muito então foi uma oportunidade (NORPOFOR, DID, 12)

(6) aquela que eu não gosto mesmo de verdade (é a aula de ensino religioso)... que o professor é um porre ((risos))... (NORPOFOR, DID, 44)

As ocorrências de (3) e (4) contêm relativas cortadoras construídas com o verbo falar (de), as quais percebemos como bastante utilizadas 
pelos informantes de nossa amostra, sobretudo quando fazem menção aos conteúdos de outros momentos da entrevista sociolinguística. Disso podemos depreender que, na interação discursiva, o informante, a fim de favorecer esclarecimentos ao documentador dos assuntos sobre os quais discorre, realiza remissões com o verbo falar, fazendo o entrevistador voltar aos conteúdos ditos anteriormente e, conforme podemos perceber, parte desses conteúdos estão expressos pelos complementos relativos, como uma espécie de gatilho, para que o documentador os acesse de maneira completa em outros momentos da entrevista (nas ocorrências 3 e 4, esses gatilhos são "parte da respiração" e "dessa moça"). Notamos ser evidente que, nessas construções descritas, muito frequentes no NORPOFOR, a anaforicidade do processo de relativização já vem bem marcada pela própria carga semântica do verbo (no caso, falar), ligando-o diretamente ao seu argumento (no caso, complemento relativo), ainda que este seja de natureza preposicionada; assim, o falante fortalezense dispensa a preposição e faz uso da estratégia de relativização cortadora.

Quanto às ocorrências (5) e (6), estas contêm estratégias de relativização cortadoras com o verbo gostar (de), construções com alto teor de gramaticalização, haja vista seu uso ser bastante fixado e frequente na comunidade de fala popular fortalezense. Ou seja, a função sintática de complemento relativo assumida pelo relativizador que é bastante cristalizada quando o falante opera a relativização em torno do verbo gostar (de), não realizando a preposição.

O interessante foi percebermos, além do mais, que a relevante atuação do complemento relativo com o verbo gostar sobre a estratégia cortadora, além de ancorar--se nessa questão dos usos cristalizados que apontam para a gramaticalização, ganha fortalecimento a partir de um aspecto laboviano característico do tipo de registro que abrange os nossos dados, o DID. Para a realização da entrevista sociolinguística, já é ponto irrevogável, na seara da linguística variacionista, que os entrevistadores devem superar o que Labov (2008) denominou de paradoxo do observador, ou seja, fazer com que os informantes não se sintam monitorados, mesmo que estejam sendo gravados; 
para isso, o entrevistador deve deixar o informante à vontade, motivando-o a narrar fatos pessoais e expressar os seus gostos.

Essa particularidade do DID permite-nos entender que, na norma popular fortalezense, o monitoramento dos informantes sobre o vernáculo diminui à medida que os documentadores do NORPOFOR lançam perguntas acerca dos gostos pessoais. Desse modo, relacionando isso ao fenômeno das estratégias de relativização, entendemos por que é especialmente frequente o uso de relativas cortadoras cujos pronomes relativos assumem função sintática de complemento relativo do verbo gostar da oração relativa. Com efeito, conforme podemos observar nas ocorrências 5 e 6 , ao discorrerem sobre o que é ou não de sua preferência - "caratê" e "aula de ensino religioso" - os informantes do NORPOFOR fazem uso de gostar no processo de relativização; esse verbo, por ter uma carga semântica factivo-emotiva ou avaliativa (PEREIRA, 1974), indica o envolvimento do informante com o conteúdo discorrido e, consequentemente, a baixa atenção à própria fala, o que o leva a dispensar o uso da preposição antecedente ao argumento desse verbo (o complemento relativo, função aderida pelo pronome relativo) e operar a relativização com a estratégia cortadora.

Findamos esta subseção afirmando que o significativo resultado para a variável função sintática do pronome relativo mostrou-se uma peculiaridade do falar fortalezense atinente à estratégia de relativização cortadora, não encontrada ou comentada pelos estudos anteriores que compõem o nosso estado da arte. Sendo assim, não confirmamos a hipótese inicial de que a relativa cortadora é beneficiada pelo objeto indireto, primeiramente porque esse fator foi desprezado em virtude dos nocautes e principalmente porque o resultado concernente ao complemento relativo é um aspecto novo trazido por nossa investigação.

Na próxima seção, apresentamos e discutimos a atuação da segunda variável apontada como relevante pelo Goldvarb X para o beneficiamento da estratégia cortadora. 


\subsection{Tipo de oração relativa}

A variável tipo de oração relativa, quanto a seu estatuto semântico, também foi selecionada como relevante na rodada estatística. Essa variável geralmente é controlada nos estudos variacionistas sobre relativização porque, segundo Kato et al. (1996), a categorização das relativas em restritivas e explicativas implica processamentos semânticos diferenciados, o que pode acarretar, por parte de um ou outro tipo, o condicionamento da escolha da estratégia de relativização a ser usada pelo falante. Observemos a tabela 2, a seguir, que apresenta a atuação desse grupo de fatores para a presente rodada.

Tabela 2. Atuação da variável tipo de oração relativa sobre as relativas cortadoras (cortadoras vs. padrão)

\begin{tabular}{cccc}
\hline FATORES & Aplica/total & Percentual & PR \\
\hline Restritiva & $588 / 654$ & $89,9 \%$ & $\mathbf{0 . 5 5 8}$ \\
Explicativa & $138 / 178$ & $77,5 \%$ & 0.298 \\
\hline
\end{tabular}

Com base na tabela 2, vemos claramente que o tipo de oração restritiva, com o PR 0.558 , beneficia a escolha pela estratégia cortadora, enquanto o tipo explicativa a inibe, com o PR 0.298.

Esse resultado faz-nos confirmar e, ao mesmo tempo, refutar a nossa hipótese inicial de que o tipo de oração restritiva privilegia as estratégias padrão e cortadoras, haja vista os dados da tabela nos indicarem que, no falar popular fortalezense, o tipo semântico restritivo realmente favorece a relativa cortadora, enquanto o tipo explicativo beneficia a padrão.

A explicação para a atuação da cláusula relativa restritiva em nossos resultados está no fato de que esse tipo semântico de relativa não amplia informações do antecedente, antes o restringe; logo a relativização é mais clara e direta, não necessitando de outra correferência (cópia) para recuperá-lo 
(como ocorre com as orações relativas copiadoras), o que conduz o falante a empregar a estratégia cortadora, conforme representa a ocorrência (7) a seguir:

(7) até porque hisTÓria eu me identifico muito bem::: eu é uma coisa que eu me sinto bem também (NORPOFOR, DID, 110)

Quanto à estratégia padrão, acreditamos que a oração relativa restritiva não a favoreça, como aponta a tabela 2 , porque a restrição consiste numa ligação mais direta da relativa com seu antecedente, dispensando o uso da preposição. Já a relativa do tipo explicativa, em face do seu caráter autônomo e apositivo, estabelece relação mais indireta, o que acarreta a escolha do falante pela estratégia padrão, cuja marca característica é o uso da preposição, conforme ilustra a ocorrência (8) que segue:

(8) na beira-mar, meu ponto predileto a volta da Jurema que é ali bem na esquina com a rua Frei MANSUETO tá? aquele ponto ali realmente é a volta da Jurema mesmo quando não... aquela parte em que ficam os barcos ancorados aquilo ali pra mim é fantástico eu digo que é o meu calmante enquanto outros se entopem de remédios o meu remédio é olhar pra beira-mar (NORPOFOR, DID, 62)

Tendo discutido analiticamente essa relevante variável para o fenômeno da relativização em nossa amostra, passemos agora para a análise do próximo grupo de fatores.

\subsection{Preposição regida pelo verbo/nome}

A terceira variável selecionada como relevante no beneficiamento da relativa cortadora foi a preposição regida pelo verbo/nome. Convém frisarmos que tal relevância era de se esperar, pois estamos investigando a relativização em contexto sintático preposicionado. Vejamos essa atuação, exposta na tabela 3 , na sequência. 
Tabela 3. Atuação da variável preposição regida pelo verbo/nome sobre as relativas cortadoras (cortadoras vs. padrão)

\begin{tabular}{cccc}
\hline FATORES & Aplica/total & Percentual & PR \\
\hline Preposição de & $116 / 118$ & $98,3 \%$ & $\mathbf{0 . 8 5 4}$ \\
Preposição com & $30 / 33$ & $90,9 \%$ & $\mathbf{0 . 5 1 3}$ \\
Preposição $e m$ & $526 / 627$ & $83,9 \%$ & 0.417 \\
\hline
\end{tabular}

Com base nos resultados da tabela 3, confirmamos a hipótese inicial de que a estratégia cortadora é favorecida quando a relativização requisita as preposições por, de, com e $a$, enquanto a padrão é prestigiada quando a relativização requisita a preposição em. Podemos notar, com base nos percentuais da tabela 3, um comportamento semicategórico da preposição de condicionando favoravelmente a relativa cortadora.

Como até agora temos percebido, as estratégias de relativização na comunidade de fala fortalezense configuram-se como um fenômeno eminentemente condicionado por fatores linguísticos, e o interessante disso é notarmos que tais fatores apresentam pontos de contato, os quais nos permitem chegar a conclusões acerca do caráter sistêmico do fenômeno variável em tela.

Isso se torna mais evidente ao depreendermos que a elevada atuação da preposição de sobre a cortadora - marcada expressivamente no PR de 0.854 - estabelece estreita relação com a significativa atuação da função sintática de complemento relativo para o pronome relativo sobre a mesma variante, sobremaneira quando esse argumento é regido sintaticamente por verbos como falar (de) e gostar (de), que são, como já discorremos e ilustramos, frequentes na fala dos informantes de nossa amostra. Isto quer dizer que, ao contemplarem, na fala, suas preferências pessoais (usando o verbo gostar) e, ao fazerem remissões discursivas em seus relatos de experiências pessoais (usando o verbo falar) com o intuito de interagir com o documentador no DID, os informantes operam estratégias de relativização 
que fazem a requisição da preposição de, embora esta sofra o corte quando o falante opta pela variante inovadora cortadora.

O nosso resultado para a omissão da preposição de, com o consequente alto índice de relativas cortadoras, reforça a reflexão investigativa traçada por Mollica (1995) acerca desse item prepositivo, quando estudou o (de)queísmo ${ }^{7}$ : por ocasião de seu "grande leque de acepções, DE pode ser considerada a mais 'palpável' (mais concreta, mais conhecida, mais comum) para quem a utiliza, sendo então inserida ou facilmente excluída [...]”.

Um outro aspecto, ainda, explica o nosso resultado quanto à variável preposição regidapelo verbo/nome. Trata-se da categorização das preposições em fortes e fracas, elucidada por Rocha Lima (2011). Consoante este gramático normativo, as preposições fracas são aquelas que, isoladamente, não possuem sentido, marcando apenas uma relação (com, de, a, em e por são as mais comuns); já as fortes, além de caráter relacional, apresentam em si mesmas uma certa significação (contra, sobre, entre etc.). Entretanto, em nosso estudo, esse último tipo de preposição não foi quantificado por conta de sua escassez na amostra coletada. Apesar disso, podemos, com base nessa categorização preposicional de Rocha Lima (2011), chegar à mesma conclusão que Corrêa (1998): na relativização, as preposições fracas, embora sejam frequentemente mais requeridas (como a preposição de em nossos dados), tendem a ser recorrentemente mais suprimidas na fala, justamente por serem desprovidas de significação em si mesmas, do que decorre o falante empregar a estratégia cortadora. Com efeito, o interlocutor tem a capacidade de reconhecer/recuperar, pelo contexto discursivo, as preposições que foram apagadas, haja vista apresentarem baixa carga semântica.

7 Segundo Mollica (1995), o queísmo e o dequeísmo constituem um único processo variável, uma vez que podem ser entendidos como uma alternância de fala caracterizada pelo binômio ausência/presença do item preposicional de diante do que, em qualquer que seja a relação sintática de complementação. 
Em se tratando da preposição com, embora seja baixo o seu número de ocorrências em nossa amostra, ela se apresenta como um fator que também beneficia a aplicação da regra, com PR 0.513. Encontramos justificativa para esse favorecimento em valores gramaticais da própria preposição com, bem como na maneira com que ela se manifesta na amostra. Em outras palavras, a requisição de com, em nossos dados, reflete os aspectos valorativos que essa preposição abarca. Em termos mais concretos, pudemos observar, em nossos dados, que, vez ou outra, quando a preposição com era requisitada no processo de relativização cortadora, os informantes expressavam, em seus conteúdos vernáculos, justamente ideias de companhia, de instrumento e de modo, peculiares a essa preposição. Vejamos as ocorrências seguintes, que reproduzem esses sentidos:

(9) o governo gasta tanto dinheiro assim no prédio numa coisa na obra tudinho e quando dá/ você vai olhar com uns dois três anos rapaz tá abandonado... aquilo ali podia ter sempre uma manutenção uma coisa... que é uma coisa eu sempre bati com um sujeito que eu ando que ele diz assim S. -- ele era do DNOCS mas se aposentou-se tá com a agente lá - ele diz rapaz a coisa mais que me endoida também S. que tu também não gosta ( ) você vê um Castanhão desse um absurdo de dinheiro que foi gasto né? depois pode notar... daqui uns quatro cinco ano tá tudo esculhambado tudo quebrado... (NORPOFOR, DID, 65)

(10) a matéria que eu gosto mais é mate eu gosto de matemática mas só que... têm umas contas aí que eu me atrapalho se atrapalho um pouco (NORPOFOR, DID, 18)

(11) algumas famílias... agem da maneira que eu penso... mas o que você vê aí na televisão... hoje em dia o corre-corre da vida... um filho... o pai chega do trabalho o filho quando o pai chega o filho tá saindo a mãe e vice-versa... então o corre-corre do dia-a-dia faz com que... é:: pais e filhos não tenham muito diálogo... (NORPOFOR, DID, 159) 
Nas ocorrências (9), (10) e (11), reproduzidas de nossa amostra, podemos perceber a estratégia de relativização cortadora requisitando o com em situações discursivas nas quais essa preposição apresenta aparatos semânticos, respectivamente, de companhia, instrumento e modo. Foram nesses contextos em que a preposição com foi mais requerida sintaticamente, favorecendo a oração relativa cortadora.

Passemos, agora, a discutir, na próxima subseção, o quarto e último grupo de fatores selecionado como relevante para a presente análise.

\subsection{Traço semântico \pm definido do antecedente}

Por último, na rodada analítica de nossa investigação, o grupo de fatores traço semântico \pm definido do antecedente foi selecionado como relevante para o favorecimento da relativa cortadora. Observemos, na tabela 4 seguinte, a atuação dessa variável.

Tabela 4. Atuação da variável traço semântico \pm definido do antecedente sobre as relativas cortadoras (cortadoras vs. padrão)

\begin{tabular}{cccc}
\hline FATORES & Aplica/total & Percentual & PR \\
\hline - definido & $173 / 186$ & $93 \%$ & $\mathbf{0 . 6 0 0}$ \\
+ definido & $553 / 646$ & $85,6 \%$ & 0.471 \\
\hline
\end{tabular}

Os dados da tabela 4 mostram-nos que, quando o antecedente da oração apresenta um traço - definido (PR 0.600), o falante opera a relativização com a estratégia cortadora, enquanto que o traço +definido (PR 0.471) inibe-a, prestigiando a variante padrão. A interpretação desses valores conduz-nos à refutação da hipótese inicial de que o traço +definido é aliado à variante cortadora. Consequentemente, divergimos dos trabalhos que corroboraram tal hipótese (MOLLICA, 1977; TARALLO, 1983; BARROS, 2000). 
Importa frisarmos que, já na investigação pioneira de Mollica (1977), explicava-se a atuação dessa variável. Segundo a autora, quando o termo relativizado carrega uma certa imprecisão ou indeterminação, isto é, um traço semântico -definido, o falante faz uso de pronomes cópias, a fim de precisar o termo relativizado, operando, por isso, com a relativa copiadora (não abordada na presente análise variável). Para o traço +definido, Mollica (1977) explica que, pelo teor de precisão do antecedente, não há necessidade de correferenciá-lo com pronome ou item lexical (cópias), conduzindo o falante a empregar a relativa cortadora.

Todavia, a comunidade de fala popular fortalezense não segue essa tendência, visto que o traço semântico -definido do antecedente beneficia também a cortadora. Esse comportamento linguístico divergente é representado pelas ocorrências reproduzidas na sequência, retiradas de nossa amostra.

(12) agora eu era bem interessada sabe? bem interessada gostava tudo que me ensinavam eu aprendia ( ) aí teve um tempo que eu fiquei assim meio desgostosa sabe? (NORPOFOR, DID, 17)

(13) mas diz que é uma praia belíssima diz que é uma praia que você mergulha e vê todo tipo de peixe você mergulha eles já vem pra cima de você... (NORPOFOR, DID, 105)

(14) ... tem uns dias que ela sai cedo né mais aí ela tem ESTÁGio... aí ela vai pro estágio...estágio que ela arranjou mais voluntário também... quer dizer por enquanto não tá dando nenhuma ajuda agente... porque até os primeiro estágio tem que ser volunTÁRIO...pra adquirir experiên::cia e também... é muito bom pro currículo né. (NORPOFOR, DID, 143)

Nos excertos de fala (12), (13) e (14), notamos claramente orações relativas cortadoras cujos antecedentes são palavras semanticamente inespecíficas ("um tempo", "uma praia" e "uns dias", respectivamente). Podemos perceber que as ocorrências acima - frequentes em nossa amostra - apresentam relativização em contexto preposicionado de instância 
adverbial, dados que não foram controlados por Mollica (1977). Daí a explicação, acreditamos, para o fato de, em nossa análise, os nossos dados não seguirem a hipótese pioneira para a variável traço semântico \pm definido do antecedente postulada pela autora. Em decorrência disso, podemos afirmar que nossos resultados não são contraditórios aos de Mollica (1977), face a escolhas metodológicas diferenciadas. Assim, podemos depreender dessas ocorrências, bastante recorrentes na fala popular de Fortaleza, que os casos de relativização cujos termos relativizados carregam o traço semântico definido condicionam favoravelmente os falantes a operarem a relativização com a estratégia cortadora. Na próxima seção, findaremos o presente artigo com nossas considerações finais.

\section{Considerações finais}

No presente artigo, o nosso objetivo foi analisar, à luz dos postulados teórico-metodológicos da Sociolinguística Variacionista, a influência dos condicionadores linguísticos e sociais sobre o fenômeno das estratégias de relativização de contexto preposicionado no português popular de Fortaleza. Os achados de nossa investigação apontaram que a estratégia de relativização cortadora se sobrepõe à variante padrão. No que tange ao condicionamento sociolinguístico gerado pela rodada estatística, o programa Goldvarb X apontou quatro grupos de fatores como aliados da aplicação da regra variável (a relativa cortadora) na fala popular de Fortaleza, a saber: o primeiro foi a função sintática do pronome relativo, no qual o complemento relativo apresentou a mais significativa atuação, seguido do adjunto adverbial; o segundo grupo foi o tipo de oração relativa quanto ao seu teor semântico, em que a cláusula relativa restritiva liderou o beneficiamento da regra de aplicação; a terceira variável independente relevante foi a preposição regida pelo verbo/nome, em que o requerimento sintático da preposição de liderou o favorecimento da relativa cortadora, acompanhado da requisição preposicional de com. A quarta e última variável elegida pelo programa estatístico foi o traço \pm definido 
do antecedente, tendo o aspecto -definido revelado-se favorável à realização da estratégia cortadora. Ao longo de nossa análise, já checamos as hipóteses levantadas inicialmente.

Em nossa análise, percebemos que as estratégias de relativização no português popular de Fortaleza é um fenômeno variável proeminentemente condicionado por fatores de natureza linguística. Isso atesta o caráter altamente sistêmico desse fenômeno, ou seja, sua variação é governada sobretudo por aspectos linguísticos peculiares da comunidade de fala analisada. Constatamos também que os resultados atinentes ao grupo de fatores função sintática do pronome relativo - notadamente o fator complemento relativo - conferiram à nossa investigação um tom inovador, uma vez que sinalizaram peculiaridades do falar fortalezense atinentes à estratégia de relativização cortadora, o que não foi encontrado pelos estudos anteriores que compuseram o nosso estado da arte.

Isso nos reporta ao argumento convincente de Labov (1978), ao afirmar que a realização de estudos sociolinguísticos não implica a preocupação unilateral de averiguar apenas os condicionadores sociais dos fenômenos em variação, mas também a atenção aos fatores estruturais que governam essa variação, o que ocorreu em nosso estudo. Isso nos aponta que há fatores linguísticos peculiares a uma comunidade que condicionam o seu falar mais do que outros.

Estamos cientes de que as possibilidades para o estudo da relativização não foram de todo esgotadas, inclusive nos próprios falares de Fortaleza. Conforme já colocamos, Pinheiro (1998) investigou as estratégias de relativização de ambiência preposicionada na fala culta, com dados do PORCUFORT Fase I; nós empreendemos esta investigação com as relativas desse mesmo contexto nos dados do DID do NORPOFOR. Não obstante, o fenômeno falta ser explorado em outros tipos de registro do NORPOFOR, bem como nos dados do PORCUFORT Fase II, que se encontra em fase de constituição e abre possibilidades até mesmo a investigações variacionistas em tempo real com as estratégias de relativização. Tais lacunas mostram que os 
estudos acerca da relativização podem ser continuados na seara variacionista dos falares de Fortaleza, permitindo uma extensão do mapeamento sociolinguístico desse fenômeno no português brasileiro.Finalizamos nosso estudo com a certeza de que ele contribui tanto para o conhecimento de especificidades variacionistas do português fortalezense quanto para a expansão dos mapeamentos sociolinguísticos do português brasileiro.

\section{Referências}

ARAÚJO, A. A.; VIANA, R. B. M.; PEREIRA, M. L. S. O banco de dados NORPOFOR. In: ARAÚJO, A. A.; VIANA, R. B. M.; PEREIRA, M. L. S. (Org.). Fotografias sociolinguísticas do falar de Fortaleza-CE. Fortaleza: EdUECE, 2018.

ARAÚJO, Aluiza Alves de. O Projeto Norma Oral do Português Popular de Fortaleza - NORPOFOR. In: CONGRESSO NACIONAL DE LINGUÍSTICA E FILOLOGIA, 15., 2011, Rio de Janeiro. Cadernos... Rio de Janeiro: CiFEFil, 2011. p. 835-845. Disponível em: <http://www.filologia.org.br/xv_ cnlf/tomo_1/72.pdf>. Acesso em: 16 maio 2019.

BARROS, A. L. O uso da relativa cortadora na fala pessoense. 2000. 99 f. Dissertação (Mestrado em Linguística) - Universidade Federal da Paraíba, João Pessoa, 2000.

BURGOS, L. E. S. Estratégias de uso das relativas em uma comunidade de fala afro-brasileira. 2003, 122f. Dissertação (Mestrado em Letras e Linguística) - Instituto de Letras, Universidade Federal da Bahia, Salvador, 2003.

CASTILHO, A. T. Nova gramática do português brasileiro. São Paulo: Contexto, 2012.

COAN, M.; CARVALHO, A. P. L. Relativização na escrita jurídica. Línguas e Letras, Cascavel, v. 17, n. 37, p. 3-18, 2016. Disponível em: http://e-revista. unioeste.br/index.php/linguaseletras/article/view/12675. Acesso em: 22 out. 2019. 
CORRÊA, V. R. Oração relativa: o que se fala e o que se aprende no português do Brasil. 1998. 165 f. Tese (Doutorado em Linguística) Instituto de Estudos da Linguagem, Universidade Estadual de Campinas, Campinas,1998. Disponível em: http://repositorio.unicamp.br/jspui/bitstream/ REPOSIP/269159/1/Correa_VilmaReche_D.pdf. Acesso em: 22 out. 2019.

FARACO, C. A. Apresentação de um clássico. In: WEINREICH, U.; LABOV, W.; HERZOG, M. I. Fundamentos empíricos para uma teoria da mudança linguística. Tradução de Marcos Bagno. São Paulo: Parábola Editorial, 2006. p. 9-29.

FURTADO DA CUNHA, M. A.; TAVARES, M. A. Linguística funcional e ensino de gramática. In: FURTADO DA CUNHA, M. A.; TAVARES, M. A. (Org.). Funcionalismo e ensino de gramática. Natal: EDUFRN, 2016. p. 12-58.

GUY, G. R. A identidade linguística da comunidade de fala: paralelismo interdialetal nos padrões da variação linguística. Organon, Porto Alegre, v. 14, n. 28-29, p. 17-32, 2000. Disponível em: https://seer.ufrgs.br/organon/ article/view/30194. Acesso em 28 out. 2019.

GUY, G. R.; ZILLES, A. Sociolinguística Quantitativa: instrumental de análise. São Paulo: Parábola Editorial, 2007.

HYMES, D. Acerca de la Competencia Comunicativa. In: Llobera, M. et al. Competencia comunicativa: documentos básicos en la enseñanza de lenguas extranjeras. Madrid: Edelsa, 1995.

KATO, M. A.; BRAGA, M. L.; CORRÊA, V. R. ROSSI, M. A. L; SIKANSI, N. S. Construções-Q na gramática do português brasileiro falado: perguntas, clivadas e relativas. In: KOCH, I. G. V. (Ed.). Gramática do português falado. V. 6: Desenvolvimentos. Campinas: Editora da UNICAMP, 1996. p. 309-374.

KOCH, I. G. V. O texto e a construção dos sentidos. 10. ed. São Paulo: Contexto, 2016. 
LABOV, W. Padrões Sociolinguísticos. Tradução de Marcos Bagno, Maria Marta Pereira Scherre, Caroline Rodrigues Cardoso. São Paulo: Parábola Editorial, 2008.

LABOV, W. Principios del cambio linguístico: factores sociales. v. 2. Madrid: Gredos, 1994.

LABOV, W. The social stratification of English in New York city. 2 ed. Cambridge: University Press, 2006.

LABOV, W. Where does the linguistic variable stop?: A response to Beatriz Lavandera. Sociolinguistics Working Paper, Texas, n. 44, p. 1-16, 1978. Disponível em: http://files.eric.ed.gov/fulltext/ED157378.pdf. Acesso em: 25 fev. 2019.

LIMA, R. Gramática normativa da língua portuguesa. 49. ed. Rio de Janeiro: José Olympio, 2011.

MOLLICA, M. C. O estudo da cópia nas construções relativas em português. 1977. 95 f. Dissertação (Mestrado em Letras) - Pontifícia Universidade Católica do Rio de Janeiro, Rio de Janeiro, 1977.

MOLLICA, M. C. (De) que falamos?. Rio de Janeiro: Tempo Brasileiro, 1995. MONTEIRO, J. L. Para compreender Labov. 2. ed. Petrópolis-RJ: Vozes, 2000.

PEREIRA, Maria Angela Botelho. Aspectos da oposição modal indicativo/ subjuntivo no Português Contemporâneo. 1974. 265 p. Dissertação (Mestrado em Linguística) - Programa de Pós-Graduação em Linguística, Universidade Federal do Rio de Janeiro, Rio de Janeiro, 1974.

PINHEIRO, C. L. A relativização no português oral culto de Fortaleza. 1998. 114 f. Dissertação (Mestrado em Linguística) - Universidade Federal do Ceará, Fortaleza, 1998. 
RAMOS, J. O. Descrição das estratégias de relativização no português de Belo Horizonte: uma abordagem variacionista. 2015. 111 f. Dissertação (Mestrado em Linguística e Língua Portuguesa) - Pontifícia Universidade Católica de Minas Gerais, Belo Horizonte, 2015. Disponível em: http://www1.pucminas.br/imagedb/documento/DOC_DSC_NOME_ ARQUI20170623140324.pdf. Acesso em: 22 out. 2019.

SANKOFF, D.; TAGLIAMONTE, S. A.; SMITH, E. Goldvarb X: A multivariate analysis application. Toronto: Department of Linguistics; Ottawa: Department of Mathematics, 2005. Disponível em: $<$ http://individual.utoronto. ca/tagliamonte/Goldvarb/GV_index.htm\#ref>. Acesso em: 10 jun. 2019.

SAUSSURE, F. Curso de linguística geral. 27. ed. São Paulo: Cultrix, 2006. SILVA, R. V. O. Análise da estrutura das orações relativas no português falado de Belo Horizonte: uma abordagem variacionista. 2011. $102 \mathrm{f}$. Dissertação (Mestrado em Linguística e Língua Portuguesa) - Pontifícia Universidade Católica de Minas Gerais, Belo Horizonte, 2011. Disponível em: http://www.biblioteca.pucminas.br/teses/Letras_SilvaRV_1.pdf. Acesso em: 22 out. 2019.

SILVA, J. C. As orações relativas no português falado em Feira de Santana-BA. 2018. 219 f. Dissertação (Mestrado em Estudos Linguísticos) Universidade Estadual de Feira de Santana, Feira de Santana, 2018. Disponível em: http://tede2.uefs.br:8080/handle/tede/691. Acesso em: 23 out. 2019.

TARALLO, F. Relativization strategies in Brazilian Portuguese. 1983. 273f. Ph.D. dissertation (degree of Doctor in Linguist) - University of Pennsylvania, Pennsylvania, 1983.

WEINREICH, U.; LABOV, W.; HERZOG, M. I. Fundamentos empíricos para uma teoria da mudança linguística. Tradução de Marcos Bagno. São Paulo: Parábola Editorial, 2006. 